\title{
Descriptive study of cases of schizophrenia in the Malian population
}

Souleymane dit Papa Coulibaly ${ }^{1,2^{*}+}$, Baba Ba ${ }^{2}$, Pakuy Pierre Mounkoro ${ }^{1,2}$, Brehima Diakite ${ }^{1,2+}$, Yaya Kassogue ${ }^{1,2+}$, Mamoudou Maiga 1,3, Aperou Eloi Dara², Joseph Traoré2, Zoua Kamaté2, Kadiatou Traoré2, Mahamadou Koné2 Boubacar Maiga ${ }^{2}$, Zoumana Diarra², Souleymane Coulibaly ${ }^{1,2}$, Arouna Togora ${ }^{1,2}, Y^{2}$ oussoufa Maiga $a^{1,4}$ and Baba Koumaré ${ }^{1,2}$

\begin{abstract}
Background: Schizophrenia is a relatively common disease worldwide with a point prevalence of around 5/1000 in the population. The aim of this present work was to assess the demographic, clinical, familial, and environmental factors associated with schizophrenia in Mali.

Methods: This was a prospective descriptive study on a series of 164 patients aged at least 12 years who came for a follow-up consultation at the psychiatry department of the University Hospital Center (CHU) Point G in Mali between February 2019 and January 2020 for schizophrenia spectrum disorder as defined by DSM-5 diagnostic criteria.

Results: Our results revealed that the male sex was predominant (80.5\%). The 25-34 age group was more represented with $44.5 \%$. The place of birth for the majority of our patients was the urban area (52.4\%), which also represented the place of the first year of life for the majority of our patients (56.1\%). We noted that the unemployed and single people accounted for 56.1 and $61 \%$ respectively. More than half of our patients $58.5 \%$ reported having reached secondary school level. With the exception of education level, there was a statistically significant difference in the distribution of demographic parameters. Familial schizophrenia cases accounted for $51.7 \%$ versus $49.3 \%$ for non-familial cases. The different clinical forms were represented by the paranoid form, followed by the undifferentiated form, and the hebephrenic form with respectively 34,28 and $17.1 \%$. We noted that almost half (48.8\%) of patients were born during the cold season. Cannabis use history was not observed in $68.7 \%$ of the patients. The proportions of patients with an out-of-school father or an out-of-school mother were 51.2 and $64.2 \%$, respectively.
\end{abstract}

Conclusion: The onset of schizophrenia in the Malian population has been associated with socio-demographic, clinical, genetic and environmental characteristics.

Keywords: Schizophrenia, Socio-demographic, Clinical, Environment, Mali

\footnotetext{
* Correspondence: sp.coulibaly@fmos.usttb.edu.ml

†Souleymane dit Papa Coulibaly, Brehima Diakite and Yaya Kassogue contributed equally to this work.

${ }^{1}$ Faculty of Medicine and Odontostomatology, University of Sciences,

Techniques and Technologies of Bamako (USTTB), 1805, Point G, Bamako,

Mali

${ }^{2}$ University Teaching Hospital Point G, Bamako, Mali

Full list of author information is available at the end of the article
}

(c) The Author(s). 2021 Open Access This article is licensed under a Creative Commons Attribution 4.0 International License, which permits use, sharing, adaptation, distribution and reproduction in any medium or format, as long as you give appropriate credit to the original author(s) and the source, provide a link to the Creative Commons licence, and indicate if changes were made. The images or other third party material in this article are included in the article's Creative Commons licence, unless indicated otherwise in a credit line to the material. If material is not included in the article's Creative Commons licence and your intended use is not permitted by statutory regulation or exceeds the permitted use, you will need to obtain permission directly from the copyright holder. To view a copy of this licence, visit http://creativecommons.org/licenses/by/4.0/ The Creative Commons Public Domain Dedication waiver (http://creativecommons.org/publicdomain/zero/1.0/) applies to the data made available in this article, unless otherwise stated in a credit line to the data. 


\section{Background}

Schizophrenia is a relatively common condition worldwide with a point prevalence of approximately 5/1000 in the population [1]. The clinical manifestations of schizophrenia are include delusions, hallucinations and disorganized speech [2]. These clinical features are interpreted as a supernatural fact from the point of view of cultural beliefs [3]. Schizophrenia is a multifactorial disease of unknown causes. However, it is accepted that several factors, in particular environmental and genetic, interact in the development of the disease $[4,5]$. According to persistent Africans beliefs, the causes of the disease are mainly of psychosocial and supernatural origin [6]. In sub-Saharan Africa, mental illnesses such as schizophrenia are caused by the invisible world imposing its authority on the visible world [7]. The visible world is everything that lives between heaven and earth, including humans, animals, water, fire, plants, earth, and air. However, the invisible world represents the origin and the final destination of any living being, in this world the geniuses, ancestors as well as the double of each being live under the authority of God. In such consideration, schizophrenia appears to be due to the possession of a person's body or mind by a jinn, a sorcerer or jealous congener [8]. Diagnostic concepts of schizophrenia are important in the management of the patient at the individual level as well as in the research of risk factors and mechanisms of causality [5].

Many authors have demonstrated the existence of a strong relationship between many factors and the risk of developing schizophrenia, in particular socio-demographic (sex, age, marital status and area of residence), socioeconomic (income level), genetic (consanguinity) and environmental (season of birth, cannabis use) [9-14]. It is noteworthy that, most of these investigations have been done in Western countries, where schizophrenia related parameters were well described. Looking at the literature review, data regarding sub-Saharan Africa are lacking, especially Mali.

Malian population in its majority like that of other African countries does not escape the popular belief that schizophrenia is due to the invisible world, that is to say of divine origin. However, the Malian urban population is gradually becoming westernized by its way of life and its access to information. As a result, the families of patients begin to reject the divine origin of the disease and would instead think that the disease is the result of narcotics consumption. In order to determine the phenotypic profile of schizophrenia in Mali and to contribute to world epidemiology data of the disease, we carried out the present study which aims to describe the socio-demographic, clinical, genetic and environmental aspects of the disease.

\section{Methods}

The study was approved by the ethics committee of the Faculty of Medicine and Odontostomatology/Faculty of Pharmacy under the number 2019/63/CE/FMPOS at the University of Sciences, Techniques and Technologies of Bamako (USTTB). Study participants were recruited in the psychiatry department of the University Hospital Center of Point G from February 2019 to January 2020. Each participant received a detailed explanation about the study and was invited to give informed consent. This is a prospective descriptive study involving a series of 164 patients aged at least 15 years followed on an outpatient basis for at least 1 year for a schizophrenia spectrum disorders such as schizophrenia, schizophreniform disorder and schizoaffective disorder according to the diagnostic criteria of DSM-5 (Diagnostic and Statistical Manual of Mental Disorders). Study participants recruitment was based on the DSM-5 criteria. The physician, using an interview guide and pre-established survey form, addressed the patient alone after having established a climate of trust. Then, the physician collected data concerning socio-demographic parameters, including age, gender, professional situation, marital status, level of education, rank in uterine siblings, clinical (age of diagnosis, type, and sub-types of schizophrenia), and environmental (place of birth and life, family's monthly income, birth season, cannabis use history) and the family history (father-mother consanguinity relationship and the number of relatives with schizophrenia) were collected for all patients. After that, the recorded files were submitted to a second physician for review for the confirmation of the DSM-5 criteria before the patient was considered for the study.

\section{Operational description of the studied parameters}

The age of the participants was determined based on the day, month and year of birth. Participant's gender was defined on the basis of the observation of a set of characteristics that distinguish male and female. The professional situation was determined according to the regular exercise or not of an activity to earn a living. The educational level of the participants correspond to the higher level achieved by the participant in the institutional education system of the country.

The rank in uterine siblings was defined according to the subsequent chronological order of the births of a mother's children. Consanguinity characterizes the sharing of a common ancestor. Schizophrenia was defined based of the DSM-5 criteria. The schizophrenia sub-types have been defined by referring to the criteria for the International Classification of Diseases 10th Edition. The concept of cannabis use refers to the positive verbal affirmation of an experience of cannabis use in the last 12 months. 


\section{Statistical analysis}

SPSS statistical package version 19.0 Software was used to analyze the data. All categorical variables were presented as proportions. We used the chi-square test to assess the relationship between the socio-demographic, clinical, genetic, environmental variables, and schizophrenia. A $p$-value $<0.05$ was considered as statistically significant.

\section{Results}

The present descriptive study concerned 164 Malian patients suffering from schizophrenia. As shown in Table 1, the patients consisted of 132 males (80.5\%), 32 females $(19.5 \%)$ with a mean age of $28.9 \pm 12.9$; range $(15-45$

Table 1 Demographic characteristics of patients with schizophrenia

\begin{tabular}{|c|c|c|c|}
\hline Parameter & $\mathbf{N}$ & $\%$ & $p$. value \\
\hline Gender & 164 & & $<0.0001$ \\
\hline Male & 132 & 80.5 & \\
\hline Female & 32 & 19.5 & \\
\hline Age & 164 & & $<0.0001$ \\
\hline $15-24$ & 36 & 22.0 & \\
\hline $25-34$ & 73 & 44.5 & \\
\hline $35-44$ & 38 & 23.2 & \\
\hline$\geq 45$ & 17 & 10.4 & \\
\hline Professional status & 164 & & $<0.0001$ \\
\hline Active worker & 71 & 43.3 & \\
\hline Retired worker & 1 & 0.6 & \\
\hline Unemployed & 92 & 56.1 & \\
\hline Marital status & 164 & & $<0.0001$ \\
\hline Single & 100 & 61 & \\
\hline Married & 51 & 31.1 & \\
\hline Divorced & 9 & 5.5 & \\
\hline Widower/widow & 4 & 2.4 & \\
\hline Level of education & 164 & & 0.411 \\
\hline Primary & 42 & 25.6 & \\
\hline Secondary & 49 & 29.9 & \\
\hline High & 39 & 23.8 & \\
\hline Unschooled & 34 & 20.7 & \\
\hline Place of birth & 164 & & $<0.0001$ \\
\hline Rural & 65 & 39.6 & \\
\hline Urban & 86 & 52.4 & \\
\hline Semi-urban & 13 & 7.9 & \\
\hline Income level of family & 164 & & $<0.0001$ \\
\hline Low & 33 & 20.1 & \\
\hline Average & 96 & 58.5 & \\
\hline High & 35 & 21.3 & \\
\hline
\end{tabular}

years). The 25-34 age group was more represented with $44.5 \%$ compared to other age groups. The place of birth of most of our patients was the urban area with $52.4 \%$ versus 39.6 and $7.8 \%$ for rural and semi-urban areas, respectively. Regarding professional status, we noted that the unemployed were more frequent with $56.1 \%$ compared to active workers (43.3\%) and retirees (0.6\%). As for marital status, single people were the most frequent with $61 \%$ compared to married (31.1\%), divorced (5.5\%) and widow/widower (2.5\%). Overall, $79.3 \%$ of patients attended school; however, patients with secondary education level were more represented compared to others (primary, high and unschooled). Patients with average income level was more represented in our study population (58.5\%) (Table 1). The socio-demographic analysis showed significant differences in the distribution of the different parameters, except the education level (Table 1).

Table 2 displays the clinical characteristics of the study participants. The distribution of familial (51.7\%) and non-familial (49.3\%) cases of schizophrenia were statistically comparable, $p=0.875$. We noted that the paranoid form was the most common clinical manifestation of schizophrenia (34.1\%) followed by the undifferentiated (28.7\%), hebephrenic (17.1\%), and other forms whose frequencies varied between 3 and $7.3 \%$. In addition, we observed a statistically significant difference in the distribution of clinical forms of schizophrenia, $p<0.0001$.

When analyzing genetic factors, we found that 30.5\% of the study participants had a history of consanguinity with their biological parents (father and mother). Among uterine siblings, the frequency of schizophrenia decreased statistically from firstborn (31.1\%) to last (1.8\%) in a total order of 9 siblings, as shown in Fig. 1.

In Table 3, analysis of data on environmental factors showed that most schizophrenic patients were born during the cold season (48.8\%) followed by the hot season (21.3\%), the rainy season (18.9\%), and the unspecified

Table 2 Clinical features of patients with schizophrenia

\begin{tabular}{llll}
\hline Parameter & N & \% & p. value \\
\hline Types of schizophrenia & 164 & & 0.875 \\
$\quad$ Family cases & 81 & 49.3 & \\
Non-family cases & 83 & 51.7 & \\
Clinical forms of schizophrenia & 164 & & $<0.0001$ \\
Paranoid & 56 & 34.1 & \\
Hebephrenic & 28 & 17.1 & \\
Catatonic & 5 & 3.0 & \\
Undifferentiated & 47 & 28.7 & \\
Post-schizophrenia depression & 8 & 4.9 & \\
Residual & 12 & 7.3 & \\
Simple & 8 & 4.9 & \\
\hline
\end{tabular}




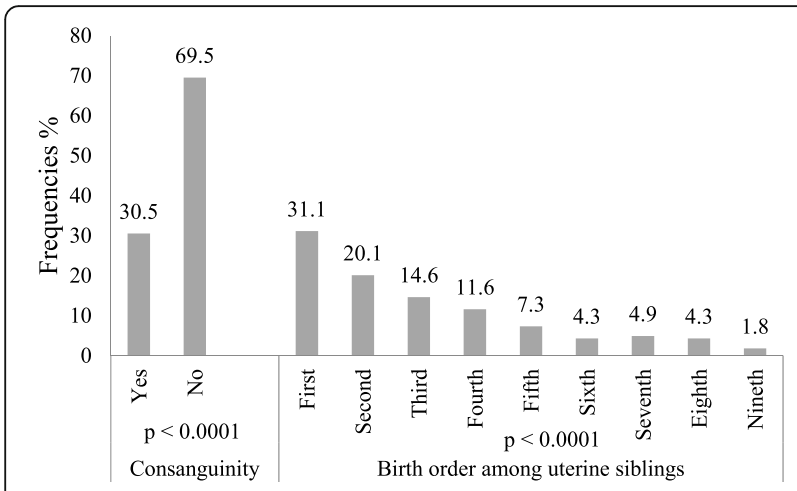

Fig. 1 Distribution of schizophrenia patients according to genetic characteristics

season [11]. History of cannabis use was absent in $68.7 \%$ of participants versus $32.3 \%$ for those who used cannabis, $p<0.0001$ (Table 3).

\section{Discussion}

Schizophrenia is one of the major contributors to the global burden of disease. Several factors have been recognized to be involved in the onset of neurodevelopmental disease, including exposure of the fetus viral influenza, rubella, or maternal toxoplasmosis [4, 15-17]. In addition, other studies have demonstrated the effect of the interaction between environmental and genetic factors $[18,19]$. As a result, the explanatory model of schizophrenia appears complex like any multifactorial disease [18]. Beyond these assumptions, schizophrenia is recognized as a ubiquitous pathology whose appearance seems to be linked to individual's age and sex. This is corroborated by the fact that the disease is most often observed in boys between 15 and 24 years old and girls between 25 and 35 years old [20]. The results of the present study showed that schizophrenia was more common in males than in females. Aleman et al. confirmed evidence for gender difference in the risk of developing schizophrenia [21]. Previous investigations have reported

Table 3 Distribution of schizophrenia patients regarding environmental characteristics

\begin{tabular}{llll}
\hline Parameter & N & $\%$ & $P$ value \\
\hline Season of birth & 164 & & $<0.0001$ \\
Cold season & 80 & 48.8 & \\
Hot season & 35 & 21.3 & \\
Rainy season & 31 & 18.9 & \\
Unspecified & 18 & 11 & \\
Cannabis use & 164 & & \\
Yes & 53 & 32.3 & \\
No & 111 & 68.7 & \\
\hline
\end{tabular}

evidence that the gender difference in schizophrenia reflects differences both in neurodevelopmental processes and in social effects on risk and disease course [22]. Markham et al. also suggested a protective role of ovarian hormones against the onset of schizophrenia [22]. Gender inequality seems to be confirmed for the Malian population. Indeed, among the patients in hospital psychiatric care in Mali, we find the predominance of the male gender and especially the $23-25$ age group [23-25]. The 25 to 34 age group was the most represented in our study. These results were comparable to those reported by Esan et al. who found that the majority of patients diagnosed with schizophrenia in the Southwest Nigerian population were 25-34 years old [11]. Weiser and $a l$. and Mounkoro et al. found similar trend with the 25-35 age group [25, 26]. Although a small number of cases of schizophrenia appear after age 40 , the majority of cases of schizophrenia occur in adolescence [27]. Mental health disorders like schizophrenia are exacerbated by the lack of structured and working activities for young people. Thus, the unemployed were the most represented in our study sample. This trend has also been observed in some studies carried out by Houngbé et al., Kelede et al. and Marwaha et al., in which significantly high prevalence of schizophrenia were observed among the unemployed in Benin, Ethiopia and the United Kingdom [27-29]. The link between the increased risk of schizophrenia and social disadvantages such as the high unemployment rate has been confirmed by other studies [7]. Generally speaking the lack of work and social support leads to a loss of personality and social independence in many young people, constituting an obstacle to the realization of their dreams. Marital status, in particular single status, has been reported to influence the course of schizophrenia (from onset of the prodrome to subsequent outcome). In our study, single people were more represented in the schizophrenic population. This trend has also been observed in the Ethiopian population, where Kebede et al. found that people who never married had a 3-folds higher risk of developing schizophrenia compared to married people. In addition, they found that the risk of the disease was 6 times higher in individuals who were separated, divorced or widowed [28]. In a review, Messias and $a l$. also reported that unmarried people are 4 times more likely to develop schizophrenia than married people [1]. Factors such as relationship avoidance, inability to start or maintain a long-term relationship can expose individual to develop schizophrenia [28]. In the African context, the celibacy of an adult or, even worse, an elderly person is an anomaly. It is perceived as a deviance that profoundly upsets cultural and social models. Celibacy could conceal serious emotional or relational suffering and social isolation. This is particularly 
true of the elderly who do not have offspring, leading to psychological discomfort. The relational vulnerability appears to affect divorced/separated and single individuals slightly more than couples or widowers. Our study did not reveal any statistical difference between education level of education and schizophrenia. These results were consistent with those of the Ethiopian and Tunisian communities [12, 28]. However, Luo et al. have reported lower risk of schizophrenia among people with additional years of study in the Chinese population [30]. Improving the level of education can prevent schizophrenia. Urban birth is a well-known risk factor for developing schizophrenia and this was supported by certain studies which found that being a male and living in an urban area was an independent risk factor for schizophrenia in Ethiopia and Ireland [28, 31]. In addition, Lundberg et al. concluded that urban birth was associated with the schizophrenia delusions subgroup in the Uganda population [32]. It has also been reported in the population of Copenhagen that the risk of schizophrenia is high in people who lived their first 5 to 15 years in an urban setting [33]. A large meta-analysis including 46,820 cases of psychosis conducted mainly in the European population, revealed that the incidence of schizophrenia measured in terms of population size or density increases significantly in the urban areas compared to rural areas with an estimated risk level of 2.27 [34]. This makes it possible to consider urbanity as a "marker" of the risk of schizophrenia [20]. Our results have shown the same trend with a predominance of schizophrenics having for place of birth and first year of life the urban environment. The risk of schizophrenia increases with the degree of urbanization at birth and this may be linked to traffic, toxins, infections, diet, social class, or selective migration [34]. In the Malian context, our result could also be linked to a bias due to the offer of available psychiatric care. In fact, in Mali, psychiatric care is available in a single university hospital center in Bamako and four other outpatient units located in the administrative regions. The capacity and the resources allocated to these units are very limited. As a result, these ambulatory care units can only ensure continuity of patient care. The country has 0.05 psychiatrists for 1000,000 inhabitants. The frequencies of family $(N=83)$ and sporadic $(N=81)$ cases were statistically similar in our study sample. The same trend was observed in the Afrikaner population in South Africa by Van der Merwe et al., $N=149$ versus $N=130$ [10]. In the contrast, most cases of schizophrenia in the Taiwanese and Chinese populations were sporadic $[35,36]$. The distribution of schizophrenia types may depend on the population studied, genetic background and environmental factors. The paranoid form was the most common form in our sample. Our results are consistent with those obtained by
Campbell et al. [37]. In addition, a study by Stomp and al. using the DSM-IV and ICD-10 criteria showed a high rate of paranoid form and a low rate for hebephrenic and catatonic forms in the Austria population of Vienna [38]. On the other hand, undifferentiated forms were very frequent in the Tunisian population followed by Paranoid forms [39]. The first-born siblings were the most affected by schizophrenia in our study $(31.1 \%$ of cases). Although, several studies have shown the predominance in the first-born, some authors recommend caution in suggesting a causal link $[1,40]$. We found a consanguinity rate of $30.5 \%$ in schizophrenic patients. In Egypt, Mansour et al. reported a rate of $46.6 \%$ in the Nile Delta region [41]. McClain et al. considered inbreeding as an age-dependent risk factor for schizophrenia [13]. Bener et al. also showed in the Qatari population that parental consanguinity was high in schizophrenic patients $(41.3 \%)$ than in nonschizophrenia controls (28.7\%) [42]. However, inbreeding has not been associated with schizophrenia in the highly consanguineous Sudanese community [43]. The association of inbreeding with schizophrenia raises the possibility of general physiological decline and recessive genetic risk factors [44]. In the African context, inbreeding is more common among lower socioeconomic groups, which in turn can lead to a high prevalence of socio-cultural and environmental risk factors for schizophrenia, such as consanguineous marriages, obstetric complications, or exposure to putative causative infectious agents. Consanguineous marriage is allowed among the Malian population, but its prohibition in terms of likely public health benefits is debated in every family. Patients born during the cool season were the most represented with $48.8 \%$ of cases and $21.3 \%$ were born in the hot season and $18.9 \%$ during the rainy season. The relationship between birth in rainy period and schizophrenia was demonstrated in previous works $[45,46]$. Several authors support this trend and several hypotheses have been put forward to explain the high frequency of this disease in the rainy season $[44,47,48]$. Among them, exposure to infectious agents, in particular the influenza virus, which is the best documented [26]. The notion of cannabis use was found in $32.3 \%$ of our schizophrenic patients and this frequency was higher than that observed in the Tunisian population (6.4\%). Schizophrenia and cannabis use seems to have a close relationship. The role of tetrahydrocannabinol (THC) in the onset of psychosis and schizophrenia in the population at risk has already been suspected [49]. Our results also showed a strong representation of schizophrenic patients whose biological parents were unschooled. Cao et al. found that parental education level and childbearing age are associated with an increased risk of schizophrenia in a Chinese population [50]. 


\section{Conclusions}

The present study assessed the risk factors associated with schizophrenia in a sample of the Malian population. Our results showed a strong representation of familial cases of schizophrenia. In addition, this study supports knowledge of the complexity of environmental factors in schizophrenia.

\section{Acknowledgments}

The authors thank the University Hospital Center of Point G, Bamako, Mali for logistical support. The authors thank all participants and medical interns in the psychiatry department. They also thank NCI D43 CA260658 and Harvard University, Boston University, Northwestern University, and University of New Mexico (HBNU) Consortium, Global Health, Fogarty International Center and the National Institutes of Health (D43 TW010543) for their training support.

\section{Authors' contributions}

All authors read and approved the final manuscript. Study concept and design: SPC, BB, PPM, SC, AT and BC. Clinical data collection: SPC, BB, PPM, AED, JT, KT, ZD Analysis and interpretation of data: SPC, BD, YK, MM. Drafting of the manuscript: SPC with assistance from by BD, YK, MM. Critical revision of the manuscript for important intellectual content: SPC, BB, PPM, BD, YK, MM, YM, AED, JT, ZK, KT, MK, BM, ZD, SC, AT, BC Obtaining supervision: AT, BC.

\section{Funding}

No funding supports.

\section{Availability of data and materials}

The datasets generated and/or analyzed in this study are available from the corresponding author upon reasonable request and with the permission of FMPOS Ethics Committee.

\section{Declarations}

\section{Ethics approval and consent to participate}

This study was approved by the FMPOS Ethics Committee (2019/63/CE/ FMPOS), Université des Sciences, des Techniques et des Technologies de Bamako (USTTB), Mali. No experiments were carried out in this study. All methods were carried out in accordance with the Declaration of Helsinki.

\section{Consent for publication}

All participants accepted and signed the written informed consent.

\section{Competing interests}

The authors declare that they have no competing interests.

\section{Author details}

${ }^{1}$ Faculty of Medicine and Odontostomatology, University of Sciences, Techniques and Technologies of Bamako (USTTB), 1805, Point G, Bamako, Mali. ${ }^{2}$ University Teaching Hospital Point G, Bamako, Mali. ${ }^{3}$ Institute for Global Health, Northwestern University, Chicago IL60611, USA. ${ }^{4}$ University Teaching Hospital Gabriel Toure, Bamako, Mali.

Received: 11 April 2021 Accepted: 10 August 2021

Published online: 20 August 2021

\section{References}

1. Messias EL, Chen C-Y, Eaton WW. Epidemiology of Schizophrenia: Review of Findings and Myths. Psychiatric Clin North Am 2007;30(3):323-38. DOI: https://doi.org/10.1016/j.psc.2007.04.007

2. Organization WH. The ICD-10 classification of mental and behavioural disorders: clinical descriptions and diagnostic guidelines. World Health Organization; 1992. Available free at https://apps.who.int/iris/handle/10665/3 7958.

3. Angermeyer MC, Carta MG, Ghachem R, Matschinger H, Millier A, Refai T, et al. Cultural Variations in Public Beliefs about Mental Disorders: A Comparison between Tunisia and Germany. Clin Pract Epidemiol Ment Health. 2020;16(Suppl-1):70-81.DOl: https://doi.org/10.2174/174501790201 6010070
4. Mednick S, Huttunen MO, Machón RA. Prenatal influenza infections and adult schizophrenia. Schizophr Bull. 1994;20(2):263-7. https://doi.org/10.1 093/schbul/20.2.263

5. Jablensky A. The diagnostic concept of schizophrenia: its history, evolution, and future prospects. Dialogues Clin Neurosci. 2010;12(3):271-87.DOl: https://doi.org/10.31887/DCNS.2010.12.3/ajablensky

6. Schizophrenia (EU-GEI) EN of NN studying G-El in. Identifying geneenvironment interactions in schizophrenia: contemporary challenges for integrated, large-scale investigations. Schizophr Bull 2014;40(4):729-736.DOl: https://doi.org/10.1093/schbul/sbu069

7. Ouango J-G, Karfo K, Kere M, Ouedraogo M, Kabore G, Ouedraogo A. Concept traditionnel de la folie et difficultés thérapeutiques psychiatriques chez les Moosé du Kadiogo. Santé Mentale au Québec. 1998;23(2):197-211 https://doi.org/10.7202/032459ar.

8. Yao YP, Yeo-Tenena YJ-M, Assi-Sedji C, Tetchi EO, Ngongi KPP, Delafosse RCJ. Itinéraires thérapeutiques des schizophrènes à Abidjan. L'information Psychiatrique. 2009;85(5):461-9 https://doi.org/10.3917/inpsy.8505.0461.

9. Budziszewska MD, Babiuch-Hall M, Wielebska K. Love and romantic relationships in the voices of patients who experience psychosis: an interpretive phenomenological analysis. Front Psychol. 2020;11:570928. https://doi.org/10.3389/fpsyg.2020.570928.

10. Van der Merwe NJ, Karayiorgou M, Ehlers R, Roos JL. Family history identifies sporadic schizoaffective disorder as a subtype for genetic studies. S Afr J Psychiatry. 2020;26:1393. https://doi.org/10.4102/sajpsychiatry.v26i0.1393.

11. Esan O, Esan A. Sexual dysfunction among patients with schizophrenia in Southwest Nigeria. J Sex Marital Ther. 2018;44(7):657-66. https://doi.org/10.1 080/0092623X.2018.1447055.

12. Aribi L, Baati I, Amami O. [Schizophrenia and education: about 32 Tunisian students suffering from schizophrenia]. Tunis Med. sept 2014;92(8-9):53641.PMID: 25815538

13. McClain L, Mansour H, Ibrahim I, Klei L, Fathi W, Wood J, et al. Age dependent association of inbreeding with risk for schizophrenia in Egypt. Schizophr Res févr. 2020;216:450-9. https://doi.org/10.1016/j. schres.2019.10.039.

14. Ben Thabet J, Charfi N, Dalhoum W, Yaich S, Maâlej Bouali M, Omri S, et al. Factors affecting the Management of Somatic Comorbidity in Tunisian patients with schizophrenia. Psychiatr Q mars. 2019;90(1):29-40. https://doi. org/10.1007/s11126-018-9605-4.

15. Brown AS. Prenatal infection as a risk factor for schizophrenia. Schizophr Bull. 2006;32(2):200-2. https://doi.org/10.1093/schbul/sbj052.

16. Moreno JL, Kurita M, Holloway T, López J, Cadagan R, Martínez-Sobrido L, et al. Maternal influenza viral infection causes schizophrenia-like alterations of 5-HT2A and mGlu2 receptors in the adult offspring. J Neurosci. 2011; 31(5):1863-72. https://doi.org/10.1523/JNEUROSCI.4230-10.2011.

17. Brown AS, Patterson PH. Maternal infection and schizophrenia: implications for prevention. Schizophr Bull. 2011;37(2):284-90. https://doi.org/10.1523/ JNEUROSCI.4230-10.2011.

18. Van Os J, Rutten BP, Poulton R. Gene-environment interactions in schizophrenia: review of epidemiological findings and future directions. Schizophr Bull. 2008;34(6):1066-82. https://doi.org/10.1093/schbul/sbn117.

19. Aleman A, Kahn RS, Selten J-P. Sex differences in the risk of schizophrenia: evidence from meta-analysis. Arch Gen Psychiatry. 2003;60(6):565-71. https://doi.org/10.1001/archpsyc.60.6.565.

20. Vilain J, Galliot A-M, Durand-Roger J, Leboyer M, Llorca P-M, Schürhoff F, et al. Les facteurs de risque environnementaux de la schizophrénie. L'Encéphale. 2013;39(1):19-28. https://doi.org/10.1016/j.encep.2011.12.007.

21. Abel KM, Drake R, Goldstein JM. Sex differences in schizophrenia. Int Review Psychiatry. 2010;22(5):417-28. https://doi.org/10.3109/09540261.2010.515205.

22. Markham JA. Sex steroids and schizophrenia. Reviews Endocrine Metabolic Disorders. 2012;13(3):187-207. https://doi.org/10.1007/s11154-011-9184-2.

23. Coulibaly SP, Maïga FI, Landouré G, Dolo H, Mounkor PP, Dara AE, et al. Facteurs associés aux troubles mentaux dans le service de psychiatrie du Centre Hospitalier Universitaire du Point G au Mali. Mali Médical. 2021;36(1): 52-57. Available free at https://www.malimedical.org/2021/04/19/annee-2 021-tome-xxxvi-n1/.

24. Albakaye M, Maiga Y, Kanikomo D, Djibo D. La dimension socioculturelle de l'épilepsie au Mali. African \& Middle East Epilepsy Journal. 2012;1(1). Available free at https://revues.imist.ma/index.php/AMEEJ/article/downloa d/3572/2598

25. Mounkoro PP, Coulibaly S, Kamate Z, Coulibaly SP, Traore J, Traore K, et al. Les Troubles Psychiatriques chez les Émigrés au Service de Psychiatrie du 
CHU Point G (Bamako). Health Sci. Dis.2019;20(6): 55-60. Available free at www.hsd-fmsb.org.

26. Weiser M, Werbeloff N, Dohrenwend BP, Levav I, Yoffe R, Davidson M. Do psychiatric registries include all persons with schizophrenia in the general population? A population-based longitudinal study. Schizophr Res. 2012; 135(1-3):187-91. https://doi.org/10.1016/j.schres.2011.12.023.

27. Houngbé JE, Gansou MG, Agongbonou R, Amonles Y, Tognide CM, Houinato D, et al. Prévalence de la schizophrénie au sud du Bénin. Rev Epidemiol Sante Publique. 2014;62:S226 https://doi.org/10.1016/j.respe.2014. 06.176 .

28. Kebede D, Alem A, Shibre T, Negash A, Fekadu A, Fekadu D, et al. Onset and clinical course of schizophrenia in Butajira-Ethiopia--a community-based study. Soc Psychiatry Psychiatr Epidemiol nov. 2003;38(11):625-31. https:// doi.org/10.1007/s00127-003-0678-4.

29. Marwaha S, Johnson S. Schizophrenia and employment. Soc Psychiatry Psychiatr Epidemiol. 2004;39(5):337-49. https://doi.org/10.1007/s00127-0040762-4.

30. Luo Y, Pang L, Zhao Y, Guo C, Zhang L, Zheng X. Gender difference in the association between education and schizophrenia in Chinese adults. BMC Psychiatry. 2020;20(1):296.DOl: https://doi.org/10.1186/s12888-020-02700-2

31. Kelly BD, O'Callaghan E, Waddington JL, Feeney L, Browne S, Scully PJ, et al. Schizophrenia and the city: a review of literature and prospective study of psychosis and urbanicity in Ireland. Schizophr Res. 2010;116(1):75-89. https://doi.org/10.1016/j.schres.2009.10.015.

32. Lundberg P, Cantor-Graae E, Rukundo G, Ashaba S, Ostergren P-O. Urbanicity of place of birth and symptoms of psychosis, depression and anxiety in Uganda. Br J Psychiatry. 2009;195(2):156-62. https://doi.org/10.11 92/bjp.bp.108.051953.

33. Pedersen CB, Mortensen PB. Evidence of a dose-response relationship between urbanicity during upbringing and schizophrenia risk. Arch Gen Psychiatry. 2001;58(11):1039-46. https://doi.org/10.1001/archpsyc.58.11.1039.

34. Vassos E, Pedersen CB, Murray RM, Collier DA, Lewis CM. Meta-analysis of the association of urbanicity with schizophrenia. Schizophr Bull. 2012;38(6): 1118-23. https://doi.org/10.1093/schbul/sbs096.

35. Chou I-J, Kuo C-F, Huang Y-S, Grainge MJ, Valdes AM, See L-C, et al. Familial Aggregation and Heritability of Schizophrenia and Co-aggregation of Psychiatric Illnesses in Affected Families. Schizophr Bull. 2017:43(5):1070-8. DOI: https://doi.org/10.1093/schbul/sbw159

36. Liang S, Deng W, Wang Q, Ma X, Li M, Brown MRG, et al. Performance of Verbal Fluency as an Endophenotype in Patients with Familial versus Sporadic Schizophrenia and Their Parents. Sci Rep. 2016;6:32597.DOI: https:// doi.org/10.1038/srep32597.

37. Campbell MM, Sibeko G, Mall S, Baldinger A, Nagdee M, Susser E, et al. The content of delusions in a sample of South African Xhosa people with schizophrenia. BMC Psychiatry. 2017;17(1):41.DOI: https://doi.org/10.1186/s12 888-017-1196-3

38. Stompe T, Ortwein-Swoboda G, Ritter K, Marquart B, Schanda H. The impact of diagnostic criteria on the prevalence of schizophrenic subtypes. Compr Psychiatry. 2005;46(6):433-9. https://doi.org/10.1016/j. comppsych.2005.03.003.

39. Ben Afia A, Aflouk Y, Saoud H, Zaafrane F, Gaha L. Bel Hadj Jrad B. Inteurleukin-8 gene variations and the susceptibility to schizophrenia. Psychiatry Res. 2020;293:113421. https://doi.org/10.1016/.jpsychres.202 0.113421 .

40. Barry H, Barry H. Birth order, family size, and schizophrenia. Arch Gen Psychiatry. 1967;17(4):435-40. https://doi.org/10.1001/archpsyc.1967.017302 80051005.

41. Hare EH, Price JS. Mental disorder and season of birth: comparison of psychoses with neurosis. Br J Psychiatry. 1969;115(522):533-40. https://doi. org/10.1192/bjp.115.522.533.

42. Bener A, Dafeeah EE, Samson N. Does consanguinity increase the risk of schizophrenia? Study based on primary health care centre visits. Ment Health Fam Med. 2012;9(4):241-8.

43. Ahmed AH. Consanguinity and schizophrenia in Sudan. Br J Psychiatry. 1979;134(6):635-6. https://doi.org/10.1192/bjp.134.6.635.

44. Mansour H, Fathi W, Klei L, Wood J, Chowdari K, Watson A, et al. Consanguinity and increased risk for schizophrenia in Egypt. Schizophr Res. 2010;120(1-3):108-12. https://doi.org/10.1016/j.schres.2010.03.026.

45. Mortensen PB, Pedersen CB, Westergaard T, Wohlfahrt J, Ewald H, Mors O, et al. Effects of family history and place and season of birth on the risk of schizophrenia. N Engl J Med. 1999;340(8):603-8. https://doi.org/10.1056/ NEJM199902253400803.

46. Speranza M. Approche psychopathologique et développementale de la schizophrénie infantile. Neuropsychiatrie de l'enfance et de l'adolescence. 2006;54(1):45-53. https://doi.org/10.1016/j.neurenf.2006.01.001.

47. Thomas G, Genest P, Walter M. L'enfance des schizophrènes: revue de la littérature. In: Annales Médico-psychologiques, revue psychiatrique. Elsevier; 2010. p. 127-133. https://doi.org/10.1016/j.amp.2008.05.021.

48. Pedersen CB, Mortensen PB. Family history, place and season of birth as risk factors for schizophrenia in Denmark: a replication and reanalysis. $\mathrm{Br} J$ Psychiatry. 2001;179(1):46-52. https://doi.org/10.1192/bjp.179.1.46.

49. Patel $\mathrm{S}$, Khan S, M S, Hamid P. The association between cannabis use and schizophrenia: causative or curative? A systematic review. Cureus [Internet]. 12(7). https://doi.org/10.7759/cureus.9309. [cité 26 nov 2020].

50. Cao B, Wang D-F, Yan L-L, McIntyre RS, Rosenblat JD, Musial N, et al. Parental characteristics and the risk of schizophrenia in a Chinese population: a case-control study. Nord J Psychiatry. 2019;73(2):90-5. https:// doi.org/10.1080/08039488.2018.1529196.

\section{Publisher's Note}

Springer Nature remains neutral with regard to jurisdictional claims in published maps and institutional affiliations.

\section{Ready to submit your research? Choose BMC and benefit from:}

- fast, convenient online submission

- thorough peer review by experienced researchers in your field

- rapid publication on acceptance

- support for research data, including large and complex data types

- gold Open Access which fosters wider collaboration and increased citations

- maximum visibility for your research: over $100 \mathrm{M}$ website views per year

At BMC, research is always in progress.

Learn more biomedcentral.com/submissions 